\title{
The Role of the Mineralocorticoid Receptor in Inflammation: Focus on Kidney and Vasculature
}

\author{
Zachary Belden $^{\mathrm{a}}$ Jeffrey A. Deiuliis ${ }^{\mathrm{a}} \quad$ Mirela Dobre $^{\mathrm{b}}$ Sanjay Rajagopalan ${ }^{\mathrm{a}, \mathrm{c}}$ \\ ${ }^{a}$ Case Cardiovascular Research Institute, ${ }^{b}$ Division of Nephrology and Hypertension, and ${ }^{\mathrm{c} H a r r i n g t o n}$ Heart and \\ Vascular Institute, Department of Medicine, Case Western Reserve University, Cleveland, $\mathrm{OH}$, USA
}

\section{Keywords}

Macrophage inflammation · Kidney fibrosis · Central nervous system inflammation · Atherosclerosis · Vascular remodeling · Cardiac hypertrophy

\begin{abstract}
Background: The remarkable success of clinical trials in mineralocorticoid receptor (MR) inhibition in heart failure has driven research on the physiological and pathological role(s) of nonepithelial MR expression. MR is widely expressed in the cardiovascular system and is a major determinant of endothelial function, smooth muscle tone, vascular remodeling, fibrosis, and blood pressure. An important new dimension is the appreciation of the role MR plays in immune cells and target organ damage in the heart, kidney and vasculature, and in the development of insulin resistance. Summary: The mechanism for MR activation in tissue injury continues to evolve with the evidence to date suggesting that activation of $M R$ results in a complex repertoire of effects involving both macrophages and T cells. MR is an important transcriptional regulator of macrophage phenotype and function. Another important feature of MR activation is that it can occur even with normal or low aldosterone levels in pathological conditions. Tissue-specific conditional models of MR expression in myeloid cells, endothelial cells, smooth
\end{abstract}

(C) 2017 S. Karger AG, Basel muscle cells and cardiomyocytes have been very informative and have firmly demonstrated a critical role of MR as a key pathophysiologic variable in cardiac hypertrophy, transition to heart failure, adipose inflammation, and atherosclerosis. Finally, the central nervous system activation of MR in permeable regions of the blood-brain barrier may play a role in peripheral inflammation. Key Message: Ongoing clinical trials will help clarify the role of MR blockade in conditions, such as atherosclerosis and chronic kidney disease.

(c) 2017 S. Karger AG, Basel

\section{Introduction}

In the 1950s, Selye et al. [1] presciently characterized the effects of aldosterone on nonepithelial tissues and postulated that spironolactone is protective in conditions of aldosterone excess. The cloning of the human mineralocorticoid receptor (MR) by Arriza et al. [2] exactly 30 years ago, spurred interest in the nonclassical aspects of aldosterone including the role of aldosterone in cardiac remodeling and fibrosis [3]. MRs are members of a superfamily of intracellular ligand-operated steroid recep-

Z.B. and J.A.D. contributed equally to this work.

\section{KARGER}

E-Mail karger@karger.com

www.karger.com/ajn
Sanjay Rajagopalan, MD

Case Cardiovascular Research Institute

Wolstein Research Building, Rm 4405

Cleveland OH 44106-010 (USA)

E-Mailsxr647@ case.edu 
tors that regulate transcription of multiple genes and other transcription factors resulting in a complex repertoire of effects. The remarkable success of clinical trials in MR inhibition through their effects on the cardiovascular system have driven research on the physiological and pathological role(s) of nonepithelial MR expression [4-6]. An important new dimension is the evolving appreciation of the role MR plays in immune cells as it relates to target organ damage (Fig. 1). In this review, we attempt to review the most significant developments related to $M R$ modulation of immune expression and new studies over the last decade that have paved the way for renewed understanding of MR-mediated cardiorenal disease.

\section{MR Structure and Expression}

The MR receptor is a 984-amino acid intracytoplasmic receptor divided into 3 domains: the $\mathrm{N}$-terminal domain that regulates transcriptional activity of the receptor; the DNA-binding domain involved in the binding of the specific response element found on the promoter of MR target genes; and finally, a ligand-binding domain responsible for the selectivity of hormone binding. MR also binds to a number of chaperones that play a pivotal role in maintaining MR in an appropriate conformation for ligand binding. Upon hormone binding, the MR dissociates from chaperone proteins, undergoes nuclear translocation, and interacts with numerous molecular partners in a coordinated and sequential manner to ensure appropriate transcriptional regulation. In the nucleus, MR recruits co-regulators (cofactors and/or corepressors) to induce the transactivation and regulation of hundreds of target genes [7]. These genes present a palindromic DNA sequence common for GR and MR called the glucocorticoid response element within their promoter. Although $\mathrm{MR}$ is regulated transcriptionally, posttranscriptional mechanisms of regulation are important and include phosphorylation and sumoylation. Very recently, ubiquitination, another posttranslational modification of $M R$, has been reported [8].

\section{MR Activation/Antagonism and Specificity-Conferring Mechanisms}

MR has been shown to bind to aldosterone at low concentrations (high picomolar) and with high affinity. MR also binds with equally high affinity to cortisol, corticosterone, deoxycorticosterone, and progesterone [9].

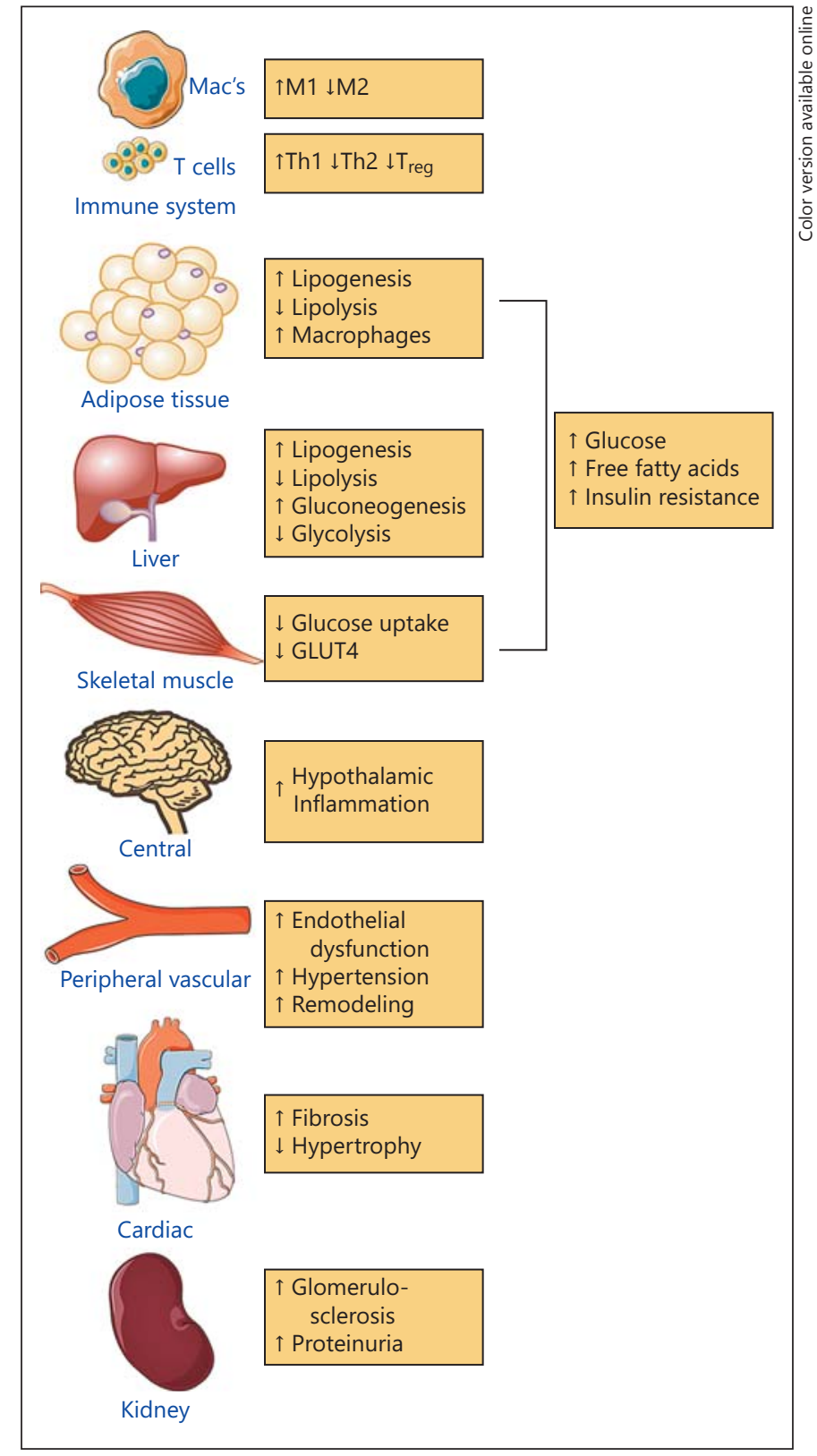

Fig. 1. Mineralocorticoid agonism or elevated aldosterone levels have a deleterious effect on organ systems and cells relevant to cardiometabolic diseases.

Since circulating physiologic glucocorticoid levels are $\sim 1,000$-fold higher than those of aldosterone on a normal diet, the issue of MR selectivity to aldosterone has been a topic of contention for decades. Studies by Funder and Minireview [9] suggested that $11 \beta$-HSD type 2 (11ß-HSD2), a high-affinity (nanomolar $K_{\mathrm{M}}$ ), low-capacity NAD-dependent dehydrogenase is expressed alongside MR, where its activity reduces the availability

Am J Nephrol 2017;46:298-314 DOI: $10.1159 / 000480652$ 
of glucocorticoids, permitting aldosterone to bind to the MR with relative exclusivity. However, the idea that the presence of $11 \beta$-HSD2 is enough to provide unfettered access to aldosterone, through "debulking" cortisol (conversion to cortisone) would require a tremendously efficient system that converts vast excesses of cortisol to cortisone in the area proximal to the MR. This mechanism is not supported by in vivo evidence in the cardiovascular, immune, and central nervous systems. Indeed, the preponderance of evidence suggests little or no $11 \beta$-HSD2 activity in the heart, inflammatory cells, and regions of the central nervous system; yet there is extensive evidence to support MR binding in these organs [10]. In addition, in vivo competition studies in adrenalectomized animals show high MR selectivity in these organs. For instance, cortisol has $\sim 30 \%$ of the apparent affinity of aldosterone in the heart. These studies firmly suggest that specificity-conferring mechanisms, other than pure enzymatic mechanisms are essential for selective aldosterone action. $11 \beta$-HSD 1 , the enzyme that converts inactive cortisone to cortisol in humans, has low affinity for glucocorticoids (micromolar $K_{\mathrm{M}}$ ) relative to $11 \beta$-HSD2, and functions both as an oxidoreductase (transfers electrons from one molecule to another) and as a dehydrogenase. The latter activity is dependent on the supply of NADPH through coupled expression of the enzyme hexose-6-phosphate dehydrogenase. Although there is plentiful evidence that myocardial cells express $11 \beta$-HSD1, reactivation of glucocorticoid is apparently limited under physiological conditions both in mice and humans. In an in vivo study in humans, the stable isotope tracer 9, 11, 12, 12-[2H]4-cortisol underwent little metabolism across the human heart [11]. Administration of the MR antagonist canrenoate in the same patients resulted in the elevation of cortisol collected from the coronary sinus, suggesting displacement of endogenous glucocorticoids. These data support the view that the cardiac MR is normally occupied by glucocorticoids rather than by aldosterone. A model that provides an explanation for glucocorticoid-mediated MR signaling in the setting of a protected MR (presence of $11 \beta-H S D 2$ ) is the concept that the activity of the enzyme $11 \beta-H S D 2$ results in a decrease in the NAD/NADH ratio (owing to generation of $\mathrm{NADH}$ ) which alters the redox state, resulting in blocking activity of MR. There is direct evidence for redox stress/state regulating the activation of other nuclear transactivating factors, and it is likely that similar changes in redox state are operant for cortisol [10]. There are undoubtedly other aspects such as conformation of the ligand-binding interactions and co-reg- ulator recruitment that may contribute to between-ligand (cortisol vs. aldosterone) differentiation in signaling $[7,12]$.

\section{MR Activation in Kidneys and Cardiovascular Tissues}

The mechanism for MR activation in tissue injury continues to evolve and suggests a complex repertoire of effects involving a multitude of mediators that are cell and context dependent. While in both animal models and humans, there is evidence that both plasma and urinary aldosterone concentrations are increased in a variety of cardiometabolic conditions, MR activation may occur in the absence of elevated aldosterone levels [13]. Recently, several studies have suggested that MR activity is also affected by factors other than its ligands including PKA, Rac-1, ubiquitin conjugating enzymes and other factors involved in the regulation of diverse nuclear receptors [14-17]. MR is widely expressed in the cardiovascular system such as in the endothelium, smooth muscle cells, and fibroblasts, and is a major determinant of endothelial function, smooth muscle tone, vascular remodeling, fibrosis, and blood pressure (BP) [18-25]. Endothelial, vascular smooth muscle, and cardiomyocyte-specific overexpression/deletion studies in animals and studies in humans, support a role for MR activation in promoting vascular oxidative stress, inflammation, proliferation, migration, vasoconstriction, vascular remodeling, and fibrosis [2634], (online suppl. Table for all online suppl. material, see www.karger.com/doi/10.1159/000480652).

In the kidneys, the classical effects of MR activation are to increase epithelial sodium channel $(\mathrm{ENaC})$ density in the distal convoluted tubule via increased expression and activation of serum and glucocorticoid regulated kinase-1 (SGK1). Phosphorylated SGK1 in turn "inhibits an inhibitor" of ENaC, NEDD4, a protein involved constitutively in the ubiquitination of $\mathrm{ENaC}$ [35]. Chronically, SGK1 may also play a role by promoting ENaC transcription through inhibition of H3K79 methyltransferase, which blocks transcription of ENaC. Mineralocorticoidsensitive inflammation and fibrosis involves the upregulation of the inflammatory transcription factor NFKB, which in turn stimulates the expression of diverse mediators including connective tissue growth factor. SGK1 also inhibits the degradation of the transforming growth factor beta (TGF $\beta$ )-dependent transcription factors Smad2/3, further promoting a profibrotic signal [36].

Aldosterone promotes the proliferation of renal fibroblasts and mesangial cells via transactivation of epidermal 
growth factor receptor and platelet-derived growth factor receptor, induces myofibroblastic transdifferentiation of mesangial and tubular epithelial cells, and directly stimulates the synthesis of profibrotic cytokines and matrix proteins [37-40]. The profibrotic response of aldosterone at least in animal models, clearly requires sodium. Studies by Shibata et al. $[15,41]$ have shown that salt can lead to the activation of MR, even in the absence of ligand resulting in a profibrotic response in the kidney and heart. Recent studies have additionally implicated an important role for the immune system in aldosterone-mediated fibrosis and tissue injury. As detailed below, the activation of the immune system appears to be an important mediator of MR-mediated effects and is a requisite for its profibrotic effects.

\section{Role of the MR in Macrophage/Monocytes}

MR appears to play a central role in regulating macrophage phenotype and function broadly through transcriptional reprogramming of monocytes/macrophages. Many of the phenotypic effects reported to be regulated by MR may reflect a broad repurposing of cellular function. Thus, while the effects of MR activation/antagonism are reported discretely, they may reflect related and connected effects. In this regard, deletion of MR in myeloid cells (MR knock out or MRKO) has been very useful in ascribing MR-dependent mechanisms in macrophages. Table 1 details the cell-specific and phenotypic effects of conditional tissue-specific deletion of MR in cardiovascular cells, including in myeloid cells.

\section{Transcriptional Reprogramming of Macrophages}

$\operatorname{PPAR} \gamma, \operatorname{PPAR} \delta$, and KLF4 are major regulators of alternate activation and are required for the maintenance of alternatively activated macrophages (Fig. 2) [42]. Macrophages in mice can be rendered pro-inflammatory (M1) in the presence of aldosterone, an effect prevented by MR antagonism which favors an anti-inflammatory, alternatively activated (M2) phenotype [43]. Conversely, MRKO in myeloid cells recapitulated the effects of MR antagonism, by shifting the phenotype to M2 (alternatively activated macrophage) and downregulating proinflammatory and profibrotic genes (TGF $\beta$ and PAI-1). In vivo, myeloid MRKO reduced aortic and cardiac macrophage recruitment, cardiac hypertrophy, fibrosis, and fetal gene reprogramming in response to AngII and LNAME (model of MR activation) suggesting that myeloid MR is crucial to adverse, fibrotic cardiovascular re-

MR and Inflammation modeling [43]. Gene expression analysis revealed significant similarity between MRKO and PPAR $\gamma$ activation. These findings were similar to another study investigating macrophages from the heart in myeloid MRKO and wild-type (WT) animals treated with vehicle or DOCA/ salt. A pro-inflammatory and profibrotic profile in response to DOCA salt was prevented in the heart of mice with myeloid MR-null macrophages [44]. Further, MRKO in macrophages diminished the activation of both AP1 and NFKB in restenosis models with effects dependent on SGK1, consistent with other studies [45, 46].

\section{Regulation of Myeloid Inflammatory Numbers and} Chemotaxis

MRKO macrophages demonstrate reduced migration de novo in response to a chemokine gradient with restenotic injury, resulting in lower macrophage content in MRKO animals vs. WT [47]. Corning Transwell ${ }^{\circledR}$ assays with conditioned media derived from LPS-stimulated MRKO macrophages induced markedly less migration of vascular smooth muscle cells and lower expression of pro-inflammatory cytokines, compared to conditional media from control macrophages [47]. Several in vivo studies involving hypertension and stroke models have demonstrated a reduction in macrophage content in mice transplanted with MRKO myeloid cells [43, 48]. Similarly, in a study of cardiac hypertrophy (transaortic constriction), a reduction in macrophages in the heart with myeloid MR deletion was noted [49]. However, two studies using a severe hypertension model (unilateral nephrectomy with $0.9 \%$ salt and L-NAME) and a uninephrectomized mouse model of DOCA salt excess, demonstrated no change in the number of tissue macrophages in the heart $[44,50]$. In many of these studies, macrophage recruitment seems to play a critical role in BP response, with evidence suggesting a CCL2-dependent movement of myeloid cells to the heart required for myeloid MRdependent effects [51]. However, all studies demonstrated rather consistent reduction in tissue fibrosis and inflammation suggesting that MR deficiency critically regulates fibrosis [43, 47, 48, 50].

\section{Regulation of ROS and Inflammatory Kinases}

Aldosterone has been shown to activate components of NAPDH oxidase in various cell types [27, 28, 52-54], and reductions in NADPH oxidase have been noted in response to MR blockade [54-56]. The degree to which these are direct, nongenomic effects is difficult to understand and is currently uncertain [57]. Rac1, a Rho family

Am J Nephrol 2017;46:298-314

DOI: $10.1159 / 000480652$ 


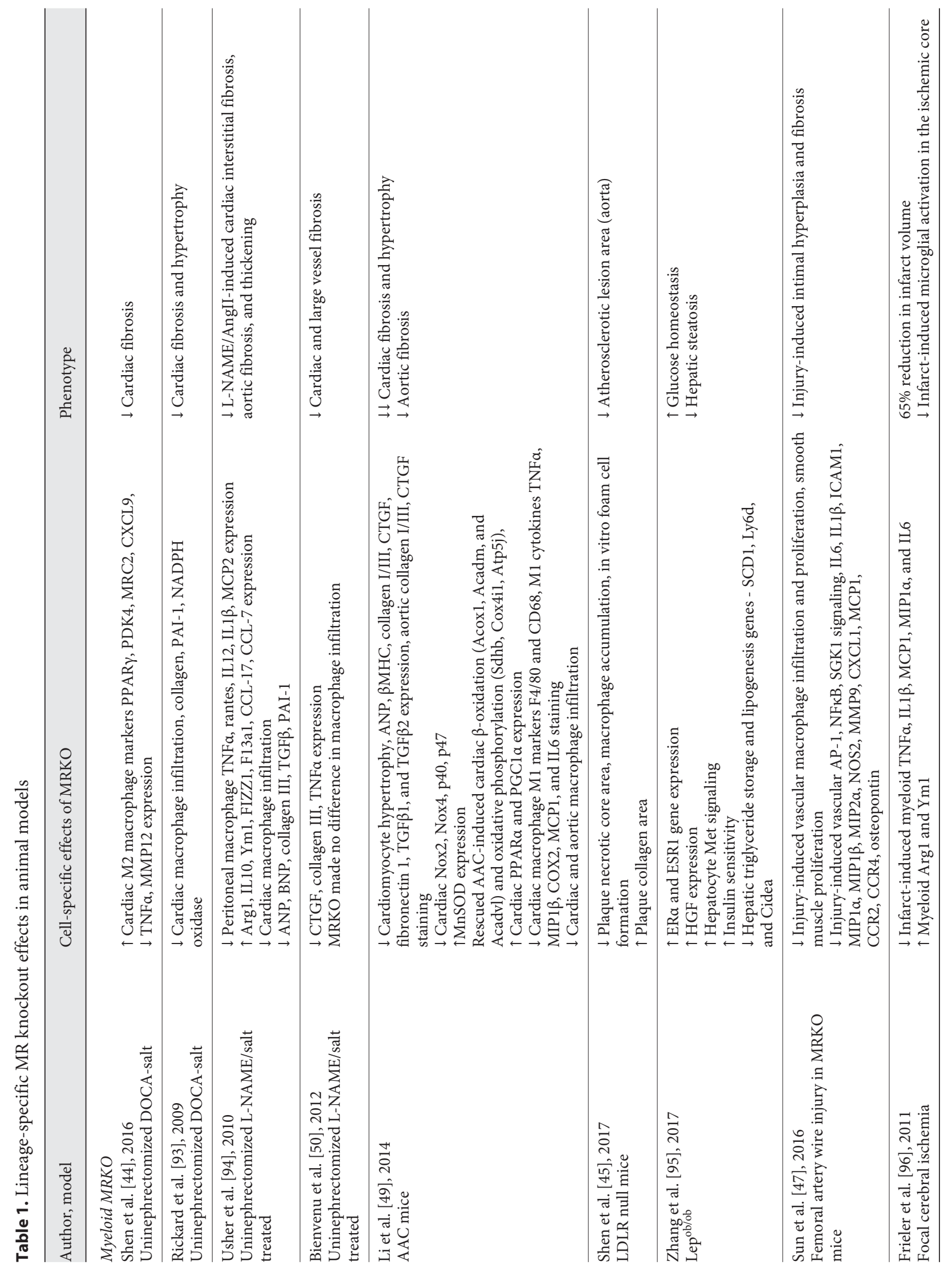




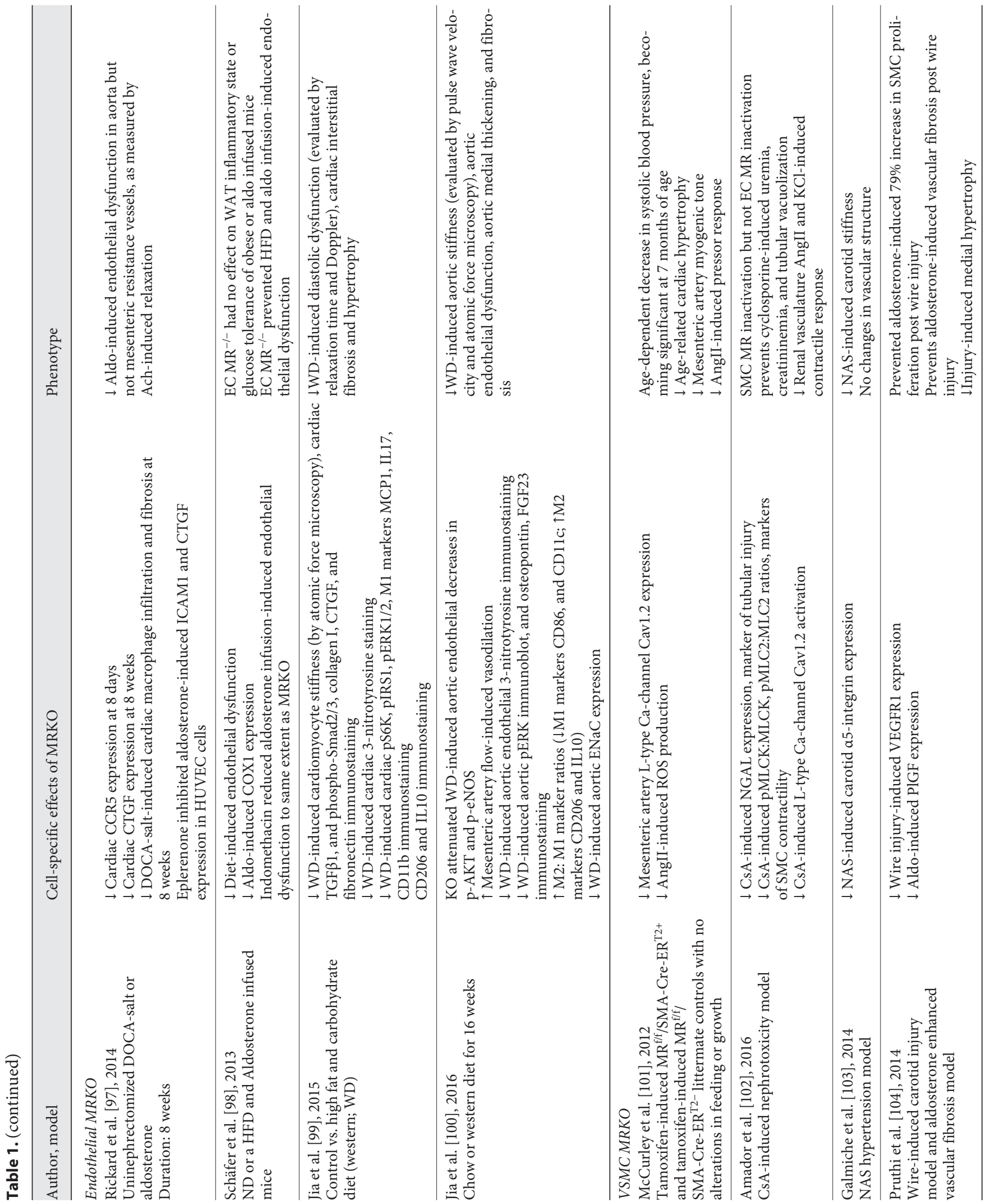

MR and Inflammation

Am J Nephrol 2017;46:298-314

303 


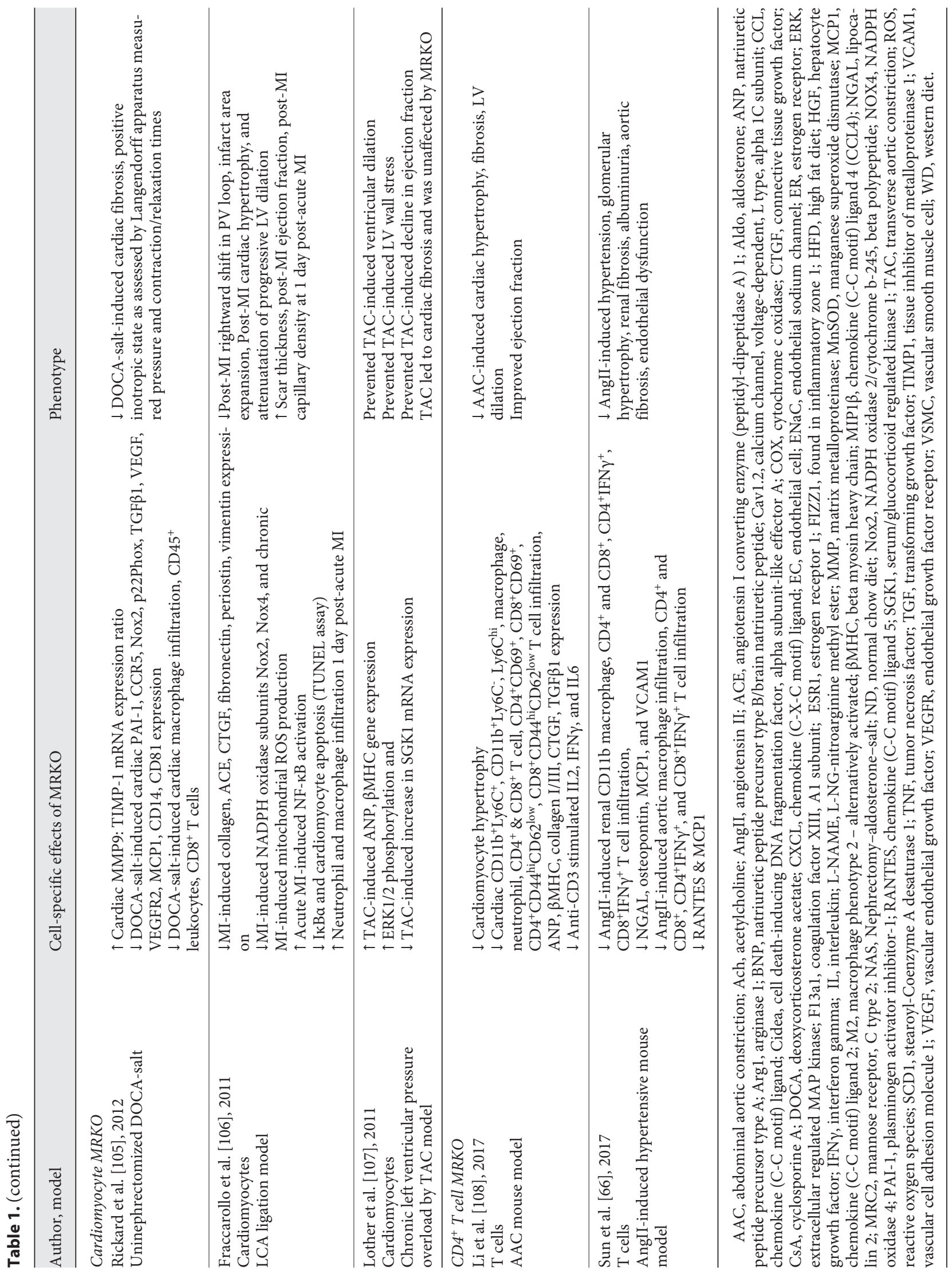




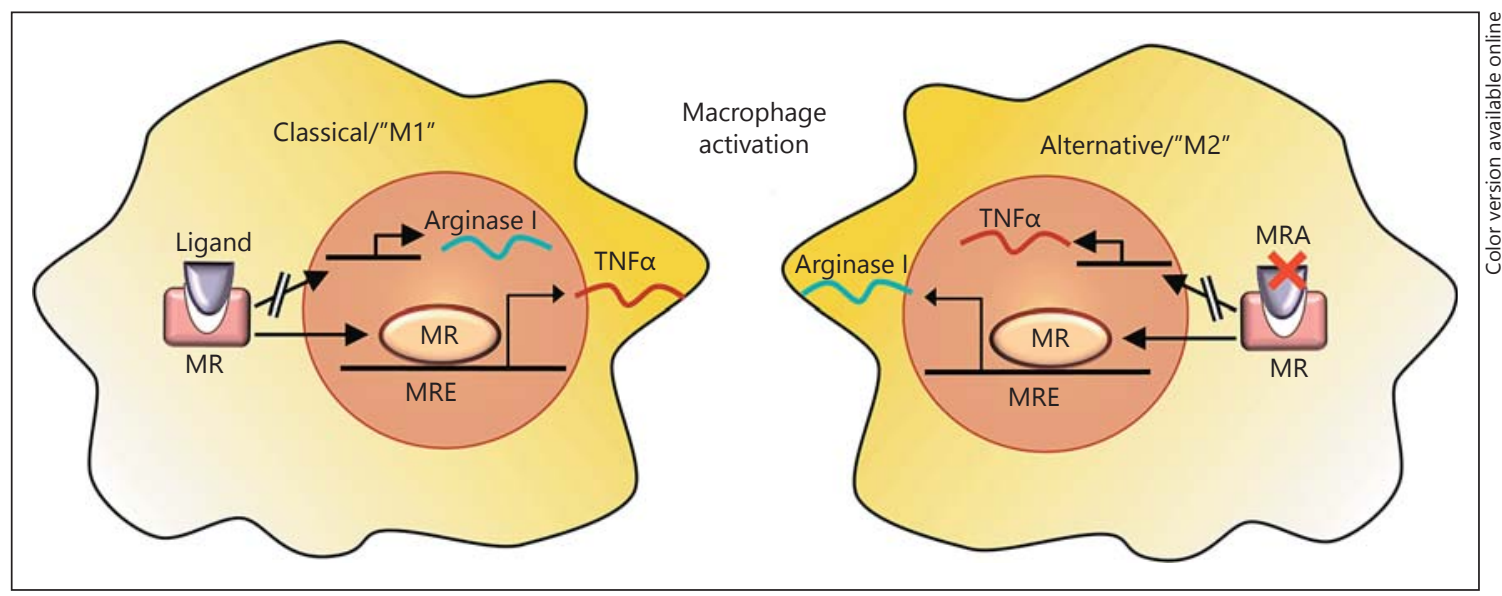

Fig. 2. Mineralocorticoid receptor agonism (ligand binding, left side) increases the classical activation of macrophages, while antagonism MRA promotes an alternative activation (right side).

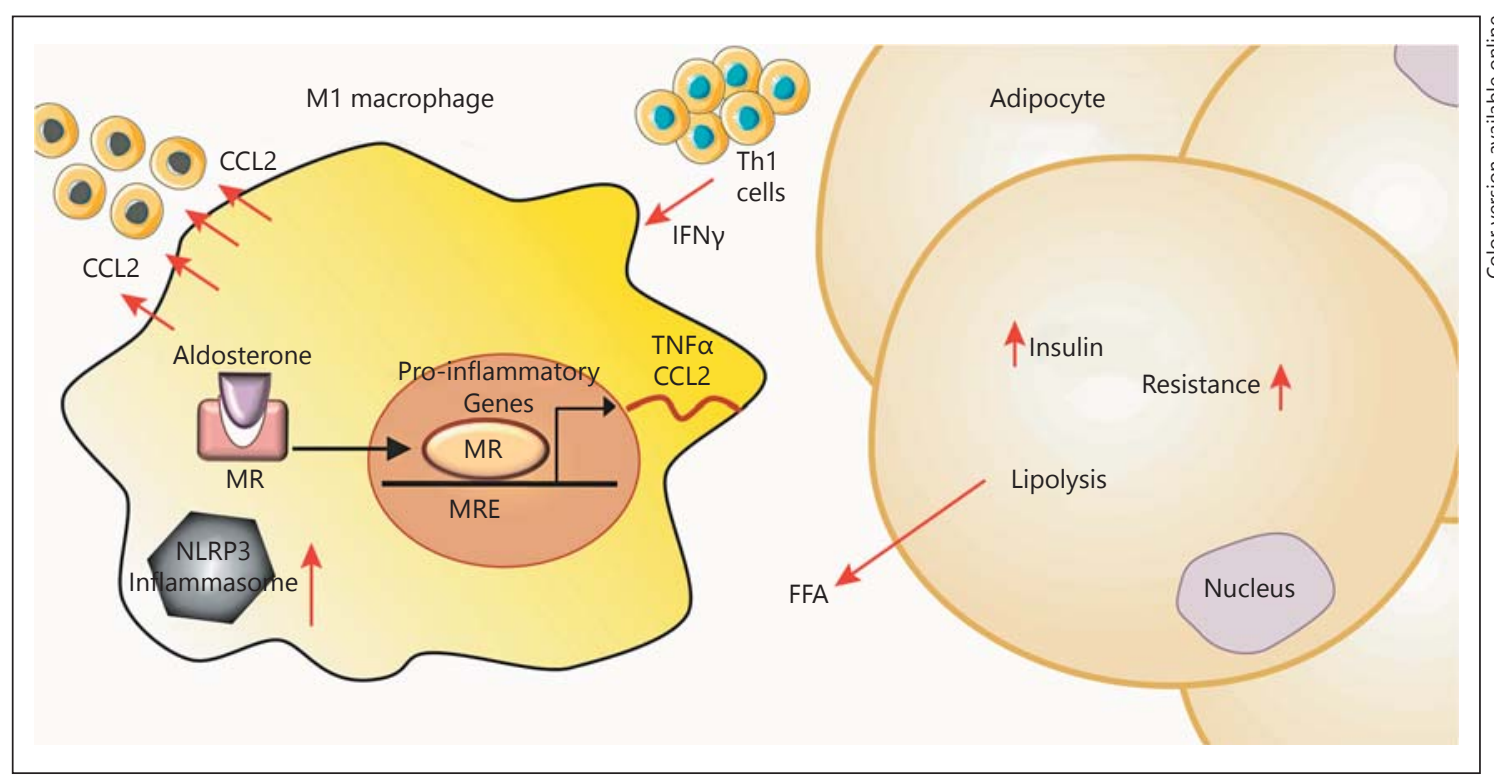

Fig. 3. Aldosterone stimulation of adipose tissue macrophages may potentiate local tissue inflammation exacerbating insulin resistance, diabetes, and atherosclerotic processes.

small GTPase, is a novel modulator of MR activity and demonstrated the pathological role of Racl-mediated MR activation in the kidney and in salt-sensitive hypertension [58]. In prior studies, overexpression of constitutively active mutant Rac1 in rat cardiomyocytes promoted nuclear accumulation of MR and increased MR-dependent transcriptional activity regardless of the ligand level implicating a potential contribution of Rac1-MR signaling in cardiac diseases $[16,41]$. Racl associates with Nox isoforms such as Nox4 (present in endothelial cells) rather than Nox2 (present in macrophages and neutro- phils), at least in the myocardium and contributes to heart failure in response to pressure overload hypertrophy. Thus, the activation of Racl and subsequent activation of MR in addition to ROS generation through Nox4 may contribute to tissue injury and transition to heart failure [41]. cJun N-terminal kinases (JNK) may also be a downstream target of MR, as bone marrow-derived macrophages exposed to LPS (classic type 1 proinflammatory mediator) significantly increased the phosphorylation of JNK, while phosphorylation of JNK is attenuated in MRnull bone marrow-derived macrophages. Analysis of oth- 
er MAPK pathways such as p38 and ERK1/2 showed equivalent phosphorylation. In this study there were no differences in phosphorylation of the NFKB pathway and I $\kappa$ Ba.

\section{Evidence for Inflammasome Activation in Myeloid} Cells in Response to Aldosterone and MR Involvement

Chronic inflammation caused by inflammasome activation is involved in many diseases including atherosclerosis, diabetes, and obesity (Fig. 3). Recently, a role for inflammasome activation in kidney injury via MR activation has been proposed; aldosterone stimulates various components of the inflammasome complex and products of inflammasome activation (IL18) lead to podocyte injury while blockade of MR reverses these effects [59]. Mice deficient in apoptosis-associated speck-like protein (ASC) had reduced renal fibrosis and inflammation without affecting macrophage numbers. Bone marrow transplantation using ASC-deficient mice marrow reduced inflammasome activation, implicating myeloid cell-derived ASC in tubulointerstitial damage and subsequent fibrotic changes in the kidney [60]. The mechanism of activation was attributed to mitochondrial-driven ROS as mitochondrial-directed antioxidant mito-TEMPO interrupted caspase activation in response to aldosterone in cultured macrophages [60]. A model of anti-glomerular basement membrane glomerulonephritis (anti-GBM GN) was used to interrogate the contribution of podocyte versus myeloid MR. The absence of MR in podocytes did not reduce immune injury in anti-GBM GN. In contrast, injury glomerular crescents, myofibroblast accumulation, and gene expression of profibrotic molecules (COL1A1, FN1, PAI-1) were all decreased in MyMRKO mice versus WT [61].

Role of Central Nervous System MR in Regulation of Peripheral Inflammation

MR activation in the brain has been linked to sympathetic hyperactivity and an increase in peripheral tissue aldosterone levels, while central MR blockade attenuates sympathetic hyperactivity $[62,63]$. In an interesting study, the time course of macrophage infiltration and apoptosis in the heart in response to central MR blockade (intracerebroventricular infusion of eplerenone, $5 \mu \mathrm{g} /$ day) was evaluated post-myocardial infarction. Central MR blockade significantly decreased CD80-positive proinflammatory M1 macrophages and increased CD163positive anti-inflammatory M2 macrophages in the infarct. Central MR blockade also reduced apoptosis of myocytes by $40-50 \%$ in the peri-infarct zone [64].

\section{Role of the MR in T Cells}

T lymphocytes play an important role in target organ damage in hypertension and atherosclerosis. Indeed, MR in $\mathrm{T}$ cells is critical in mediating fibrosis in the heart and kidney. T cell deficient in MR reduces ventricular remodeling in hypertension caused by trans-aortic constriction. This was associated with reduced $\mathrm{T}$ cell activation markers and inflammation in heart. Activation of MR resulting in increased Th17 T cells could contribute to cardiac fibrosis. Conversely, treatment with IL-17 blocking antibodies prevented DOCA/salt induced cardiac and renal fibrosis in rats [65]. Recently, it has also been shown that MR may interact with a critical transcription factor in $\mathrm{T}$ cells, NFAT1, and activator protein-1 to control interferon gamma in $\mathrm{T}$ cells and regulate $\mathrm{BP}$ and target organ damage in an AngII-infusion murine model [66]. MRA (mineralocorticoid receptor antagonism) by eplerenone and $\mathrm{T}$ cell-specific MR ablation (TMRKO) in mice resulted in reduced abdominal aortic constriction (AAC)induced cardiac hypertrophy, with reduced measures of cardiac fibrosis (\% fibrotic area, $\beta \mathrm{MHC}$, collagen I/III, connective tissue growth factor, and TGF $\beta 1$; Table 1) [67]. Measures of cardiac function (e.g., LV end-systolic volume) were partially preserved in TMRKO-AAC versus WT-AAC and LV-dilation/LVH was attenuated. Post-ACC cardiac neutrophil and monocyte/macrophage $\left(\mathrm{CD} 11 \mathrm{~b}^{+} \mathrm{Ly}_{6 \mathrm{G}}{ }^{+}\right.$; CD $11 \mathrm{~b}^{+} \mathrm{Ly}_{6} \mathrm{C}^{\text {hi }}$ respectively) content was dramatically lower in TMRKO mice.

\section{Role of the MR and Effect of MR Antagonism in the Treatment of Cardiovascular and Renal Diseases}

Pharmacological and clinical studies over $>20$ years have defined the importance of the MR in hypertension and heart failure which will not be discussed here. There are studies that demonstrated an impact of MRA in patients with risk factors, with improvement in surrogate outcomes related to LV mass and hypertrophy (Table 2).

\section{Effect of MRA in Cardiac Hypertrophy, Fibrosis, and Diastolic Dysfunction}

Online supplementary Table details studies involving MRA that have demonstrated efficacy in reducing fibrosis and hypertrophy in a variety of animal models irrespective of aldosterone levels. A consistent effect of MRA is its impact on fibrosis and reduction of left ventricular
306

Am J Nephrol 2017;46:298-314 DOI: $10.1159 / 000480652$
Belden/Deiuliis/Dobre/Rajagopalan 


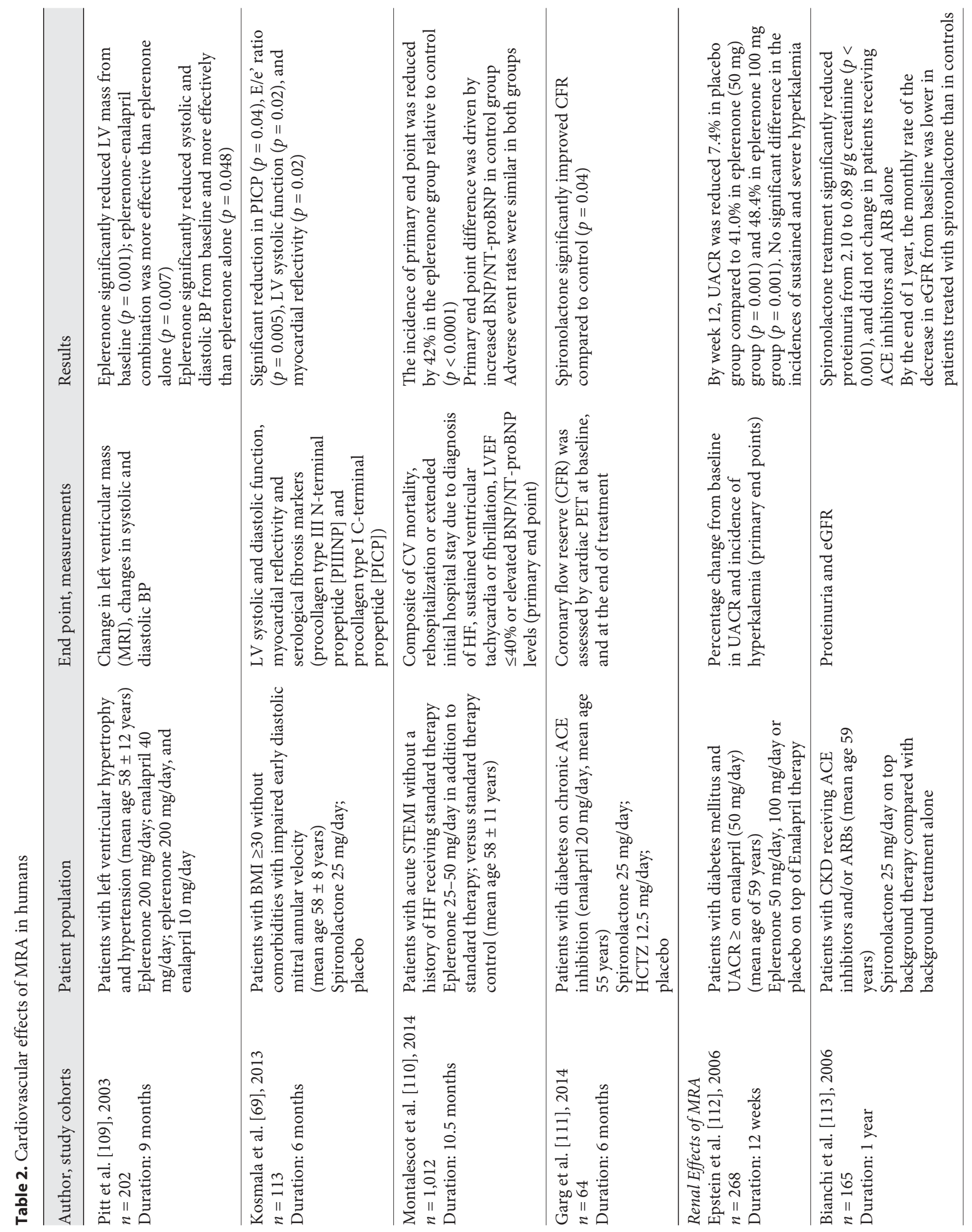

MR and Inflammation

Am J Nephrol 2017;46:298-314 


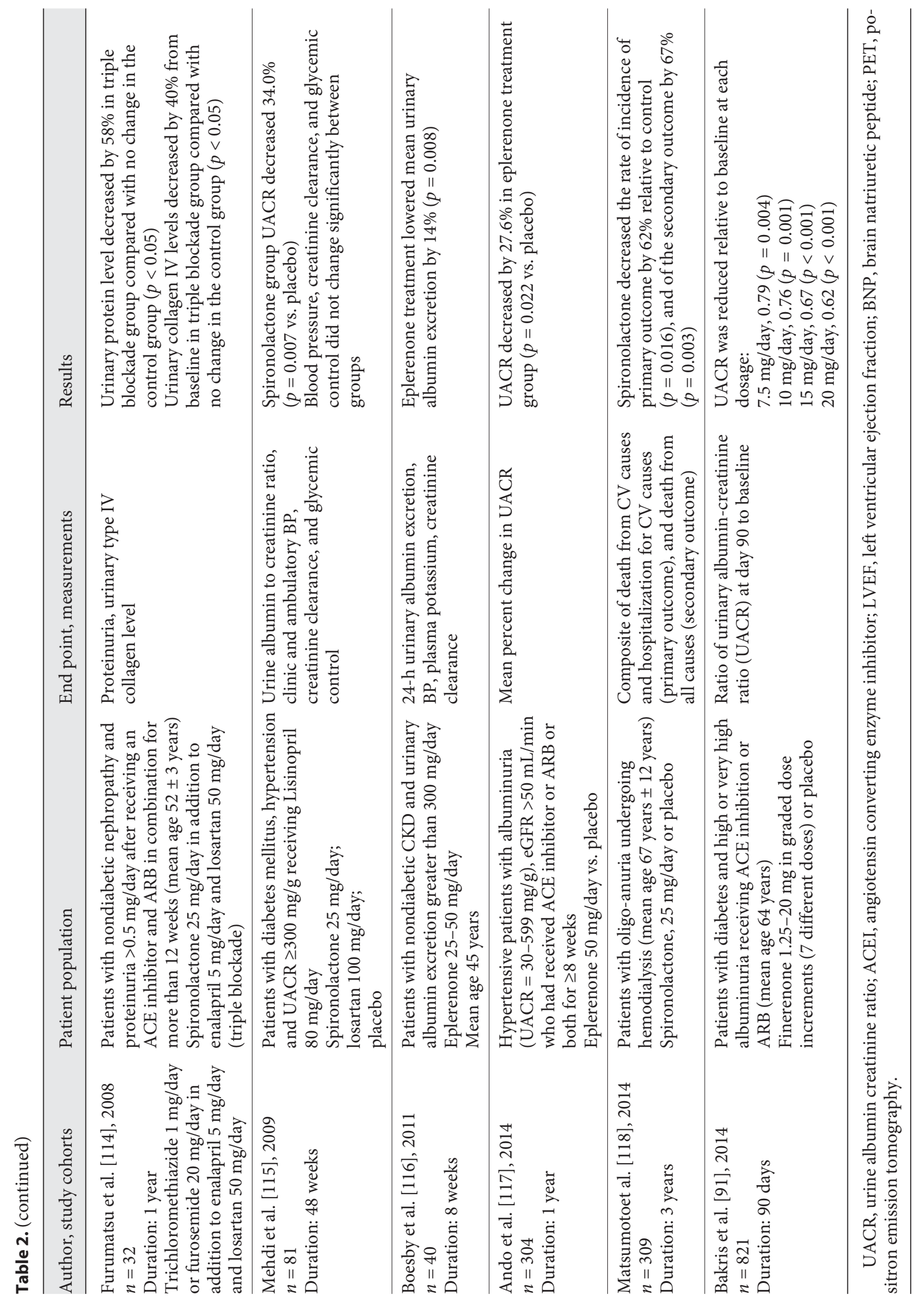


hypertrophy. In humans, MRA reduced LVH in patients on top of ACE inhibition [68]. While these effects may rely on BP reduction, data from animal models seem to support an effect that may occur independently of BP. A small study in obese patients demonstrated that MRA (spironolactone) for 6 months can improve diastolic dysfunction, subclinical markers of systolic dysfunction (global longitudinal strain), a surrogate marker of myocardial fibrosis (integrated backscatter, echo) and circulating markers of fibrosis (PICP) [69]. Although results from the Treatment of Preserved Cardiac Function Heart Failure with an aldosterone antagonist trial were negative, subset analysis suggests benefits in patients with evidence of definitive heart failure who were medication compliant [70-72].

\section{Effect of MRA in Atherosclerosis}

Proof-of-concept experiments from our group using eplerenone in a rabbit model of atherosclerosis provided one of the first lines of evidence that MRA may improve vascular function and redox stress independent of aldosterone levels. New Zealand white male rabbits were fed $1 \%$ cholesterol chow (HL) or normal chow for 6 weeks to induce endothelial dysfunction and then randomized to receive eplerenone or placebo $(100 \mathrm{mg} / \mathrm{kg})$ for 6 additional weeks [56]. Eplerenone normalized peak endotheliumdependent relaxation and reduced $\mathrm{O}_{2}{ }^{-}$in the aorta of high cholesterol fed animals. A number of studies have demonstrated an impact of MRA in reducing atherosclerosis in mouse models, including reduction of inflammatory cell infiltration, increased M2 markers, smooth muscle proliferation, and reduced pro-inflammatory cytokines in plaques (online suppl. Table). Studies in monkeys have also demonstrated important effects of eplerenone in reducing aortic intimal volume (intravascular ultrasound) and improving acetylcholine-induced vasorelaxation [73]. In models of experimental thrombosis, aldosterone enhances thrombosis while spironolactone reverses this effect [74]. In recent studies, $\mathrm{LDLR}^{-/-}$chimeric mice with bone marrow cells from floxed (control) mice or from myeloid $\mathrm{MR}^{-1-}$ demonstrated reduced atherogenesis, suggesting that MR in myeloid cells likely promotes atherogenesis. Further chimeric ApoE $\mathrm{E}^{-/-}$mice with myeloid MRKO also exhibited reduced atherogenesis in response to AngII, an effect mediated in part by reduced foam cell formation and enhanced cholesterol efflux [45].

While the role of MRA in secondary prevention in patients with post-myocardial infarction and symptoms of

MR and Inflammation heart failure is well known, there are data suggesting that use of MRA early post-MI in patients with STEMI and LV dysfunction may be beneficial [75]. In the REMINDER study $(n=1,012)$, in patients with STEMI without HF, eplerenone reduced the composite end point of CV mortality, rehospitalization, extended hospital stay, due to $\mathrm{HF}$, sustained ventricular tachycardia or fibrillation, ejection fraction $\leq 40 \%$, or elevated BNP/NT-proBNP at 1 month. The end point was primarily driven by persistent elevation of BNP/NT-ProBNP in the placebo group. In contrast to earlier studies such as EMPHASIS-HF, this was a low risk population without HF or low EF with a low event rate $(0.4 \%$ morality rate through the trial). Further the drug was administered early on after presentation, with the first dose of study drug administered within $24 \mathrm{~h}$ of the onset of symptoms of acute MI and preferably within $12 \mathrm{~h}$. There is limited data supporting a role for aldosterone in the progression of atherosclerosis. In human studies, polymorphisms of the aldosterone synthase gene (Cyp11ß2) have been associated with plaque size on MRI. Plasma aldosterone levels have been associated with nonfatal cardiovascular events and CV death. In a study of 848 patients, plasma aldosterone was the only independent predictor of plaque progression (carotid ultrasound) in the first 2 years of the study [76].

\section{Effect of MRA on Proteinuria and Progression of Chronic Kidney Disease}

The beneficial impact of renin-angiotensin-aldosterone system (RAS) blockade with ACE-I and ARB in both diabetic and nondiabetic chronic kidney disease (CKD) has been demonstrated in multiple animal models and human studies (online suppl. Table). Two previously published meta-analysis studies published initially in 2009 and updated in 2014 demonstrated that the addition of MRA to RAS blockade reduced BP and proteinuria in CKD $[77,78]$. An updated meta-analysis that included previously unpublished data as well as including data from 3 studies which were not considered in the previous meta-analysis supported previous findings [79]. A total of 19 trials (1,646 patients) were included, of which 8 were done in patients with diabetic nephropathy. Fourteen (889 patients) compared spironolactone plus ACE-I or ARB with ACE-I or ARB alone, and 5 trials (757 patients) compared eplerenone plus ACE-I or ARB to ACE-I or ARB alone. The follow-up period of included trials was $<1$ year and the mean baseline eGFR was $>35 \mathrm{~mL} /$ $\min / 1.73 \mathrm{~m}^{2}$, therefore the impact of addition of MRA to

Am J Nephrol 2017;46:298-314

DOI: $10.1159 / 000480652$ 
RAS blockade on long-term renal outcomes or mortality in the later stages of CKD cannot be evaluated. In random effects meta-analysis, addition of MRA to RAS inhibitors resulted in a reduction in systolic BP from baseline of -5.7 and diastolic BP of $-1.7 \mathrm{~mm} \mathrm{Hg}$, respectively. The GFR fell by $-3.2 \mathrm{~mL} / \mathrm{min} / 1.73 \mathrm{~m}^{2}$. MR antagonism reduced the weighted mean protein/albumin excretion by $38.7 \%$. MRA was associated with 3-fold increased risk of hyperkalemia above the predefined trial limit. Diabetic CKD patients, however, were not at a greater risk of developing hyperkalemia than patients with CKD of alternative etiology $(p=0.38)$. Number needed to harm for 1 year of treatment, calculated from trials reporting at least one case of hyperkalemia, was 10 (95\% CI 5-27). The addition of MRA to RAS blockers led to a moderate increase from baseline potassium compared to ACE-I and/or ARB alone, both at end-of-trial visit $(0.19 \mathrm{mmol} / \mathrm{L}$ [95\% CI $0.07-0.31] ; 16$ trials; $\left.n=1,356 ; I^{2}=83.8 \%\right)$.

\section{MRA and Insulin Resistance and Type 2 Diabetes}

A number of reviews have already detailed in vitro, experimental and human evidence linking aldosterone/ MR activation with IR [80-82]. The visceral adipose RAS system synthesizes aldosterone, expresses MR, and predicts IR in both humans and animal models [82]. Adipocyte overexpression of MR results in metabolic syndrome and enhanced vascular contractility, and suggests an independent contribution outside of MR in inflammatory cells in adipose [83]. In patients with nondiabetic stages 2-5 CKD, treatment with spironolactone ameliorated insulin resistance. In the same study, insulin resistance in nephrectomized rats was improved with spironolactone presumably via adipose overexpression of the rate limiting enzyme for aldosterone, CYP11 $\beta 2$ and the downstream effector of MR, SGK-1 [84]. Spironolactone has also been shown to prevent insulin resistance in response to diuretics [85]. However, treatment of individuals with uncomplicated obesity over 6 weeks with spironolactone $50 \mathrm{mg}$, did not appear to improve insulin sensitivity index assessed by Matsuda method. It is possible that this study was performed in metabolically healthy obesity, although the insulin sensitivity index was $<5$ indicating potential insulin resistance [86]. MR activation may affect IR through multiple mechanisms that include attenuation of insulin signaling in the heart, vasculature, and skeletal muscle. This may include impairment of expression of insulin receptor and substrate, decreased GLUT4 expression, abnormal phosphorylation of IRS, and activation of multiple stress kinases downstream of insulin receptor/ IRS leading to the attenuation of insulin signaling [87]. Recently, caveolin-1 appears to be an additional mediator of MR action. Caveolin-1 knockout mice exhibit features of insulin resistance and oxidative stress with the effects being ameliorated by MR blockade. In humans, individuals with a specific mutation of caveolin-1 also appear to be more insulin-resistant [88].

\section{Conclusion}

Based on the central role MR plays in the pathogenesis of target organ damage, there is optimism that the use of MRA could benefit patients with a variety of cardiometabolic diseases to prevent complications. The advantages of MRA use for a broad spectrum of patients are far beyond theoretical and are supported by a vast body of data over the last 5 decades. However, there are challenges in the use of these agents. The identification of patients who may truly benefit from MRA is an important issue, as demonstrated in Treatment of Preserved Cardiac Function Heart Failure [71, 89]. Additionally, hyperkalemia is a concern, particularly in patients with advanced CKD. Whether the use of nonsteroidal MRA's can minimize hyperkalemia, while allowing continued benefit of MRA is an exciting area of investigation. Quantitative wholebody labeling studies with $\left[{ }^{14} \mathrm{C}\right]$-labeled finerenone, a novel nonsteroidal MRA, show equal distribution in heart and kidney tissues in contrast to disproportionate renal deposition for steroidal MRAs such as eplerenone or spironolactone, an aspect believed to be important in the lower incidence of hyperkalemia despite comparable $\mathrm{IC}_{50}$ (24 nM for spironolactone vs. $18 \mathrm{nM}$ for finerenone) [90]. Different dose strengths of finerenone have been investigated in 823 randomized patients with type 2 diabetes mellitus (T2DM) and diabetic kidney disease receiving standard of care (i.e., ACEIs/ARBs) and either once-daily finerenoneor placebo [91].FIGARO-DKD(NCT2545049, $n=6,400)$ and FIDELIO-DKD (NCT2540993, $n=4,800$ ) are 2 randomized, double-blind, placebo-controlled, parallel-group, multicenter, phase 3 studies that investigate the safety and efficacy of finerenone in the reduction of cardiovascular morbidity and mortality, and progression of CKD in subjects with T2DM and diabetic kidney disease. Apararenone, a novel nonsteroidal MRA (MT3995), is being tested in nonalcoholic steatohepatitis (NCT2923154) and in diabetic nephropathy (NCT2676401). The Mineralocorticoid Receptor Antagonism in Diabetic Atherosclerosis study will test the util- 
ity of MR antagonism in patients with T2DM with CKD, at high risk for cardiovascular complications [92]. The coprimary efficacy end point will be percentage change in total atheroma volume in thoracic aorta and left ventricular mass at 52 weeks in patients treated with spironolactone versus placebo. Secondary outcomes include 24 -h mean systolic BP, central aortic BP, and insulin resistance at 6 weeks. A novel measure in the study will be changes in candidate miRNAs that regulate expression of NR3C2 (MR gene) as well as measuring monocyte/macrophage polarization in response to therapy with spironolactone. These studies may extend the utility of MRA and make these agents attractive adjuncts to statins in the prevention of cardiometabolic complications.

\section{Disclosure Statement}

The authors would like to acknowledge the support of R01HL127422-02 awarded to Dr. Rajagopalan in this grant.

\section{References}

1 Selye H: Anticortisol action of aldosterone. Science 1955; 121:368-369.

2 Arriza JL, Weinberger C, Cerelli G, Glaser TM, Handelin BL, Housman DE, et al: Cloning of human mineralocorticoid receptor complementary DNA: structural and functional kinship with the glucocorticoid receptor. Science 1987;237:268-275.

3 Brilla CG, Pick R, Tan LB, Janicki JS, Weber KT: Remodeling of the rat right and left ventricles in experimental hypertension. Circ Res 1990;67:1355-1364.

4 Pitt B, Zannad F, Remme WJ, Cody R, Castaigne A, Perez A, et al: The effect of spironolactone on morbidity and mortality in patients with severe heart failure. Randomized Aldactone Evaluation Study Investigators. N Engl J Med 1999;341:709-717.

5 Zannad F, McMurray JJ V, Krum H, van Veldhuisen DJ, Swedberg K, Shi H, et al: EMPHASIS-HF (eplerenone CHF). N Engl J Med 2011;364:11-21.

6 Pitt B, Stier CT Jr, Rajagopalan S: Mineralocorticoid receptor blockade: new insights into the mechanism of action in patients with cardiovascular disease. J Renin Angiotensin Aldosterone Syst 2003;4:164-168.

7 Fuller PJ, Yang J, Young MJ: 30 years of the mineralocorticoid receptor: coregulators as mediators of mineralocorticoid receptor signalling diversity. J Endocrinol 2017;234:T23T34.

8 Faresse N: Post-translational modifications of the mineralocorticoid receptor: How to dress the receptor according to the circumstances? J Steroid Biochem Mol Biol 2014;143:334-342.

9 Funder JW: Minireview: aldosterone and mineralocorticoid receptors: past, present, and future. Endocrinology 2010;151:50985102.

10 Funder J: 30 years of the mineralocorticoid receptor: mineralocorticoid receptor activation and specificity-conferring mechanisms: a brief history. J Endocrinol 2017;234:T17-T21.

11 Iqbal J, Andrew R, Cruden NL, Kenyon CJ, Hughes KA, Newby DE, et al: Displacement of cortisol from human heart by acute administration of a mineralocorticoid receptor an- tagonist. J Clin Endocrinol Metab 2014;99: 915-922.

12 Hellal-Levy C, Fagart J, Souque A, RafestinOblin ME: Mechanistic aspects of mineralocorticoid receptor activation. Kidney Int 2000;57:1250-1255.

13 Kawarazaki W, Fujita T: The role of aldosterone in obesity-related hypertension. Am J Hypertens 2016;29:415-423.

14 Massaad C, Houard N, Lombès M, Barouki R: Modulation of human mineralocorticoid receptor function by protein kinase A. Mol Endocrinol 1999;13:57-65.

15 Shibata S, Nagase M, Yoshida S, Kawarazaki W, Kurihara $\mathrm{H}$, Tanaka H, et al: Modification of mineralocorticoid receptor function by Rac1 GTPase: implication in proteinuric kidney disease. Nat Med 2008;14:1370-1376.

16 Shibata S, Fujita T: The kidneys and aldosterone/mineralocorticoid receptor system in salt-sensitive hypertension. Curr Hypertens Rep 2011;13:109-115.

17 Yokota K, Shibata H, Kurihara I, Kobayashi S, Suda N, Murai-Takeda A, et al: Coactivation of the N-terminal transactivation of mineralocorticoid receptor by Ubc9. J Biol Chem 2007;282:1998-2010.

18 Lombès M, Oblin ME, Gasc JM, Baulieu EE, Farman N, Bonvalet JP: Immunohistochemical and biochemical evidence for a cardiovascular mineralocorticoid receptor. Circ Res 1992;71:503-510.

19 Viengchareun S, Le Menuet D, Martinerie L, Munier M, Pascual-Le Tallec L, Lombès M: The mineralocorticoid receptor: insights into its molecular and (patho)physiological biology. Nucl Recept Signal 2007;5:e012.

20 Duprez DA, De Buyzere ML, Rietzschel ER, Taes Y, Clement DL, Morgan D, et al: Inverse relationship between aldosterone and large artery compliance in chronically treated heart failure patients. Eur Heart J 1998;19:13711376.

21 Farquharson CA, Struthers AD: Aldosterone induces acute endothelial dysfunction in vivo in humans: evidence for an aldosterone-induced vasculopathy. Clin Sci (Lond) 2002; 103:425-431.
22 MacFadyen RJ, Barr CS, Struthers AD: Aldosterone blockade reduces vascular collagen turnover, improves heart rate variability and reduces early morning rise in heart rate in heart failure patients. Cardiovasc Res 1997; 35:30-34.

23 Grandi AM, Imperiale D, Santillo R, Barlocco E, Bertolini A, Guasti L, et al: Aldosterone antagonist improves diastolic function in essential hypertension. Hypertension 2002; 40: 647-652.

24 Briet M, Schiffrin EL. The role of aldosterone in the metabolic syndrome. Curr Hypertens Rep 2014;163-172.

25 Nguyen Dinh Cat A, Griol-Charhbili V, Loufrani L, Labat C, Benjamin L, Farman N, et al: The endothelial mineralocorticoid receptor regulates vasoconstrictor tone and blood pressure. FASEB J 2010;24:24542463.

26 Sun Y, Zhang J, Lu L, Chen SS, Quinn MT, Weber KT: Aldosterone-induced inflammation in the rat heart: role of oxidative stress. Am J Pathol 2002;161:1773-1781.

27 Keidar S, Kaplan M, Pavlotzky E, Coleman R, Hayek T, Hamoud S, et al: Aldosterone administration to mice stimulates macrophage $\mathrm{NADPH}$ oxidase and increases atherosclerosis development: a possible role for angiotensin-converting enzyme and the receptors for angiotensin II and aldosterone. Circulation 2004;109:2213-2220.

28 Miyata K, Rahman M, Shokoji T, Nagai Y, Zhang GX, Sun GP, et al: Aldosterone stimulates reactive oxygen species production through activation of NADPH oxidase in rat mesangial cells. J Am Soc Nephrol 2005; 16 : 2906-2912.

29 Van Belle E, Bauters C, Wernert N, Hamon M, McFadden EP, Racadot A, et al: Neointimal thickening after balloon denudation is enhanced by aldosterone and inhibited by spironolactone, and aldosterone antagonist. Cardiovasc Res 1995;29:27-32.

30 Xiao F, Puddefoot JR, Vinson GP: Aldosterone mediates angiotensin II-stimulated rat vascular smooth muscle cell proliferation. J Endocrinol 2000;165:533-536. 
31 Ohmine T, Miwa Y, Takahashi-Yanaga F, Morimoto S, Maehara Y, Sasaguri T: The involvement of aldosterone in cyclic stretchmediated activation of NADPH oxidase in vascular smooth muscle cells. Hypertens Res 2009;32:690-699.

32 Young M, Head G, Funder J: Determinants of cardiac fibrosis in experimental hypermineralocorticoid states. Am J Physiol 1995;269(4 pt 1):E657-E662.

33 Brown NJ, Nakamura S, Ma L, Nakamura I, Donnert E, Freeman M, et al: Aldosterone modulates plasminogen activator inhibitor-1 and glomerulosclerosis in vivo. Kidney Int 2000;58:1219-1227.

34 Delcayre C, Silvestre JS, Garnier A, Oubenaissa A, Cailmail S, Tatara E, et al: Cardiac aldosterone production and ventricular remodeling. Kidney Int 2000;57:1346-13451.

35 Pearce D, Soundararajan R, Trimpert C, Kashlan OB, Deen PM, Kohan DE: Collecting duct principal cell transport processes and their regulation. Clin J Am Soc Nephrol 2015; 10:135-146.

36 Artunc F, Lang F: Mineralocorticoid and SGK1-sensitive inflammation and tissue fibrosis. Nephron Physiol 2014;128:35-39.

37 Huang LL, Nikolic-Paterson DJ, Ma FY, Tesch GH: Aldosterone induces kidney fibroblast proliferation via activation of growth factor receptors and PI3K/MAPK signalling. Nephron Exp Nephrol 2012;120:e115-e122.

38 Zhang A, Jia Z, Guo X, Yang T: Aldosterone induces epithelial-mesenchymal transition via ROS of mitochondrial origin. Am J Physiol Renal Physiol 2007;293:F723-F731.

39 Lai L, Chen J, Hao CM, Lin S, Gu Y: Aldosterone promotes fibronectin production through a Smad2-dependent TGF-beta1 pathway in mesangial cells. Biochem Biophys Res Commun 2006;348:70-75.

40 Chen D, Chen Z, Park C, Centrella M, McCarthy T, Chen L, et al: Aldosterone stimulates fibronectin synthesis in renal fibroblasts through mineralocorticoid receptor-dependent and independent mechanisms. Gene 2013;531:23-30.

41 Ayuzawa N, Nagase M, Ueda K, Nishimoto M, Kawarazaki W, Marumo T, et al: Rac1-mediated activation of mineralocorticoid receptor in pressure overload-induced cardiac injury. Hypertension 2016;67:99-106.

42 Wynn TA, Chawla A, Pollard JW: Macrophage biology in development, homeostasis and disease. Nature 2013;496:445-455.

43 Usher MG, Duan SZ, Ivaschenko CY, Frieler RA, Berger S, Schutz G, et al: Myeloid mineralocorticoid receptor controls macrophage polarization and cardiovascular hypertrophy and remodeling in mice. J Clin Invest 2010; 120:3350-3364.

44 Shen JZ, Morgan J, Tesch GH, Rickard AJ, Chrissobolis S, Drummond GR, et al: Cardiac tissue injury and remodeling is dependent upon MR regulation of activation pathways in cardiac tissue macrophages. Endocrinology 2016;157:3213-3223.
45 Shen ZX, Chen XQ, Sun XN, Sun JY, Zhang WC, Zheng XJ, et al: Mineralocorticoid receptor deficiency in macrophages inhibits atherosclerosis by affecting foam cell formation and efferocytosis. J Biol Chem 2017;292:925935.

46 Terada Y, Ueda S, Hamada K, Shimamura Y, Ogata $\mathrm{K}$, Inoue $\mathrm{K}$, et al: Aldosterone stimulates nuclear factor-kappa B activity and transcription of intercellular adhesion molecule-1 and connective tissue growth factor in rat mesangial cells via serum- and glucocorticoidinducible protein kinase-1. Clin Exp Nephrol 2012;16:81-88

47 Sun JY, Li C, Shen ZX, Zhang WC, Ai TJ, Du LJ, et al: Mineralocorticoid receptor deficiency in macrophages inhibits neointimal hyperplasia and suppresses macrophage inflammation through SGK1-AP1/NF-kB pathways significance. Arterioscler Thromb Vasc Biol 2016;36:874-885.

48 Frieler RA, Meng H, Duan SZ, Berger S, Schütz G, He Y, et al: Myeloid-specific deletion of the mineralocorticoid receptor reduces infarct volume and alters inflammation during cerebral ischemia. Stroke 2011;42: 179-185.

49 Li C, Zhang YY, Frieler RA, Zheng XJ, Zhang WC, Sun XN, et al: Myeloid mineralocorticoid receptor deficiency inhibits aortic constriction-induced cardiac hypertrophy in mice. PLoS One 2014;9:e110950.

50 Bienvenu LA, Morgan J, Rickard AJ, Tesch GH, Cranston GA, Fletcher EK, et al: Macrophage mineralocorticoid receptor signaling plays a key role in aldosterone-independent cardiac fibrosis. Endocrinology 2012;153: 3416-3425.

51 Shen JZ, Morgan J, Tesch GH, Fuller PJ, Young MJ: CCL2-dependent Macrophage recruitment is critical for mineralocorticoid receptor-mediated cardiac fibrosis, inflammation, and blood pressure responses in male mice. Endocrinology 2014;155:1057-1066.

52 Iwashima F, Yoshimoto T, Minami I, Sakurada $\mathrm{M}$, Hirono $\mathrm{Y}$, Hirata $\mathrm{Y}$ : Aldosterone induces superoxide generation via Rac1 activation in endothelial cells. Endocrinology 2008; 149:1009-1014.

53 Keidar S, Kaplan M, Aviram M: Angiotensin II-modified LDL is taken up by macrophages via the scavenger receptor, leading to cellular cholesterol accumulation. Arterioscler Thromb Vasc Biol 1996;16:97-105.

54 Bayorh MA, Rollins-Hairston A, Adiyiah J, Lyn D, Eatman D: Eplerenone suppresses aldosterone/salt-induced expression of NOX-4. J Renin Angiotensin Aldosterone Syst 2011; 12:195-201.

55 Suzuki J, Iwai M, Mogi M, Oshita A, Yoshii T, Higaki J, et al: Eplerenone with valsartan effectively reduces atherosclerotic lesion by attenuation of oxidative stress and inflammation. Arterioscler Thromb Vasc Biol 2006;26: 917-921.

56 Rajagopalan S, Duquaine D, King S, Pitt B,6Patel P: Mineralocorticoid receptor antag- onism in experimental atherosclerosis. Circulation 2002;105:2212-2216.

57 Hayashi H, Kobara M, Abe M, Tanaka N, Gouda E, Toba H, et al: Aldosterone nongenomically produces NADPH oxidase-dependent reactive oxygen species and induces myocyte apoptosis. Hypertens Res 2008;31: 363-375.

58 Nishimoto M, Fujita T: Renal mechanisms of salt-sensitive hypertension: contribution of two steroid receptor-associated pathways. Am J Physiol Renal Physiol 2015;308:F377F387.

59 Bai M, Chen Y, Zhao M, Zhang Y, He JC, Huang S, et al: NLRP3 inflammasome activation contributes to aldosterone-induced podocyte injury. Am J Physiol Renal Physiol 2017;312:F556-F564.

60 Kadoya H, Satoh M, Sasaki T, Taniguchi S, Takahashi M, Kashihara N: Excess aldosterone is a critical danger signal for inflammasome activation in the development of renal fibrosis in mice. FASEB J 2015;29:3899-3910.

61 Huang LL, Nikolic-Paterson DJ, Han Y, Ozols E, Ma FY, Young MJ, et al: Myeloid mineralocorticoid receptor activation contributes to progressive kidney disease. J Am Soc Nephrol 2014;25:2231-2240.

62 Lal A, Veinot JP, Leenen FH: Critical role of CNS effects of aldosterone in cardiac remodeling post-myocardial infarction in rats. Cardiovasc Res 2004;64:437-447.

63 Francis J, Weiss RM, Wei SG, Johnson AK, Beltz TG, Zimmerman K, et al: Central mineralocorticoid receptor blockade improves volume regulation and reduces sympathetic drive in heart failure. Am J Physiol Heart Circ Physiol 2001;281:H2241-H2251.

64 Leenen FH, Huang BS, Yu H, Yuan B: Brain "Ouabain" mediates sympathetic hyperactivity in congestive heart failure. Circ Res 1995; 77:993-1000.

65 Amador CA, Barrientos V, Peña J, Herrada AA, González M, Valdés S, et al: Spironolactone decreases DOCA-salt-induced organ damage by blocking the activation of T helper 17 and the downregulation of regulatory $\mathrm{T}$ lymphocytes. Hypertension 2014;63:797-803.

66 Sun XN, Li C, Liu Y, Du LJ, Zeng MR, Zheng $\mathrm{XJ}$, et al: T-cell mineralocorticoid receptor controls blood pressure by regulating interferon-gamma. Circ Res 2017;120:1584-1597.

67 Li C, Sun XN, Zeng MR, Zheng XJ, Zhang YY, Wan Q: Mineralocorticoid receptor deficiency in T cells attenuates pressure overload-induced cardiac hypertrophy and dysfunction through modulating T-cell activation. Hypertension 2017;70:137-147.

68 Pitt B, Reichek N, Metscher B, Phillips R, Roniker B, Kleiman J, Burns D; on behalf of the Eplerenone 017 Investigators: Efficacy and Safety of Eplerenone, Enalapril, and Eplerenone/Enalapril Combination Therapy in Patients with Left Ventricular Hypertrophy. Presented at the 51st Annual Scientific Session of the American College of Cardiology, Atlanta, GA, 2002. 
69 Kosmala W, Przewlocka-Kosmala M, Szczepanik-Osadnik H, Mysiak A, Marwick TH: Fibrosis and cardiac function in obesity: a randomised controlled trial of aldosterone blockade. Heart 2013;99:320-326.

70 Pfeffer MA, Claggett B, Assmann SF, Boineau $\mathrm{R}$, Anand IS, Clausell N, et al: Regional variation in patients and outcomes in the Treatment of Preserved Cardiac Function Heart Failure With an Aldosterone Antagonist (TOPCAT) trial. Circulation 2015;131:34-42.

71 Anand IS, Solomon SD, Claggett B, Shah SJ, O'Meara E, Boineau R, et al: Prognostic value of baseline BNP and NT-ProBNP and its interaction with spironolactone in patients with heart failure and preserved ejection fraction in the TOPCAT Trial. Circulation 2015; 132:A14922.

72 de Denus S, O’Meara E, Desai AS, Claggett B, Lewis EF, Leclair G, et al: Spironolactone metabolites in TOPCAT - new insights into regional variation. N Engl J Med 2017;376: 1690-1692.

73 Takai S, Jin D, Muramatsu M, Kirimura K, Sakonjo H, Miyazaki M: Eplerenone inhibits atherosclerosis in nonhuman primates. Hypertension 2005;46:1135-1139.

74 Bodary PF, Sambaziotis C, Wickenheiser KJ, Rajagopalan S, Pitt B, Eitzman DT: Aldosterone promotes thrombosis formation after arterial injury in mice. Arterioscler Thromb Vasc Biol 2006;26:233-233.

75 Pitt B, Remme W, Zannad F, Neaton J, Martinez F, Roniker B, et al: Eplerenone, a selective aldosterone blocker, in patients with left ventricular dysfunction after myocardial infarction. N Engl J Med 2003;348:1309-1321.

76 de Rita O, Hackam DG, Spence JD: Effects of aldosterone on human atherosclerosis: plasma aldosterone and progression of carotid plaque. Can J Cardiol 2012;28:706-711.

77 Navaneethan SD, Nigwekar SU, Sehgal AR, Strippoli GF: Aldosterone antagonists for preventing the progression of chronic kidney disease: a systematic review and meta-analysis. Clin J Am Soc Nephrol 2009;4:542-551.

78 Bolignano D, Palmer SC, Navaneethan SD, Strippoli GF: Aldosterone antagonists for preventing the progression of chronic kidney disease; in Strippoli GF (ed): Cochrane Database of Systematic Reviews. Chichester, UK, John Wiley \& Sons, Ltd, 2014, p CD007004.

79 Currie G, Taylor AH, Fujita T, Ohtsu H, Lindhardt M, Rossing P, et al: Effect of mineralocorticoid receptor antagonists on proteinuria and progression of chronic kidney disease: a systematic review and meta-analysis. BMC Nephrol 2016;17:127.

80 Briet M, Schiffrin EL: The role of aldosterone in the metabolic syndrome. Curr Hypertens Rep 2011;13:163-172.

81 Gilbert KC, Brown NJ: Aldosterone and inflammation. Curr Opin Endocrinol Diabetes Obes 2010;17:199-204.

82 Bruder-Nascimento T, da Silva MA, Tostes $\mathrm{RC}$ : The involvement of aldosterone on vascular insulin resistance: implications in obe- sity and type 2 diabetes. Diabetol Metab Syndr 2014;6:90.

83 Nguyen Dinh Cat A, Antunes TT, Callera GE, Sanchez A, Tsiropoulou S, Dulak-Lis MG, et al: Adipocyte-specific mineralocorticoid receptor overexpression in mice is associated with metabolic syndrome and vascular dysfunction: role of redox-sensitive PKG-1 and Rho kinase. Diabetes 2016;65: 2392-2403.

84 Hosoya K, Minakuchi H, Wakino S, Fujimura $\mathrm{K}$, Hasegawa K, Komatsu M, et al: Insulin resistance in chronic kidney disease is ameliorated by spironolactone in rats and humans. Kidney Int 2015;87:749-760.

85 Raheja P, Price A, Wang Z, Arbique D, Adams-Huet B, Auchus RJ, et al: Spironolactone prevents chlorthalidone-induced sympathetic activation and insulin resistance in hypertensive patients. Hypertension 2012;60:319325.

86 Garg R, Kneen L, Williams GH, Adler GK: Effect of mineralocorticoid receptor antagonist on insulin resistance and endothelial function in obese subjects. Diabetes Obes Metab 2014; 16:268-272.

87 Vecchiola A, Lagos CF, Carvajal CA, Baudrand R, Fardella CE: Aldosterone production and signaling dysregulation in obesity. Curr Hypertens Rep 2016;18:20.

88 Baudrand R, Gupta N, Garza AE, Vaidya A, Leopold JA, Hopkins PN, et al: Caveolin 1 modulates aldosterone-mediated pathways of glucose and lipid homeostasis. J Am Heart Assoc 2016;5:pii: e003845.

89 Shah AM, Claggett B, Sweitzer NK, Shah SJ, Anand IS, O'Meara E, et al: Cardiac structure and function and prognosis in heart failure with preserved ejection fraction: findings from the echocardiographic study of the Treatment of Preserved Cardiac Function Heart Failure with an Aldosterone Antagonist (TOPCAT) Trial. Circ Heart Fail 2014;7:740751.

90 Kolkhof P, Bärfacker L: 30 years of the mineralocorticoid receptor: mineralocorticoid receptor antagonists: 60 years of research and development. J Endocrinol 2017;234:T125T140.

91 Bakris GL, Agarwal R, Chan JC, Cooper ME, Gansevoort RT, Haller H, et al: Effect of finerenone on albuminuria in patients with diabetic nephropathy: a Randomized Clinical Trial. JAMA 2015;314:884.

92 Rajagopalan S, Alaiti MA, Broadwater K, Goud A, Gaztanaga J, Connelly K, et al: Design of the magnetic resonance imaging evaluation of Mineralocorticoid Receptor Antagonism in Diabetic Atherosclerosis (MAGMA) Trial. Clin Cardiol 2017;DOI: 10.1002/clc.22718.

93 Rickard AJ, Morgan J, Tesch G, Funder JW, Fuller PJ, Young MJ: Deletion of mineralocorticoid receptors from macrophages protects against deoxycorticosterone/salt-induced cardiac fibrosis and increased blood pressure. Hypertension 2009;54:537-543.
94 Usher MG, Duan SZ, Ivaschenko CY, Frieler RA, Berger S, Schütz G, et al: Myeloid mineralocorticoid receptor controls macrophage polarization and cardiovascular hypertrophy and remodeling in mice. J Clin Invest 2010;120:3350-3364.

95 Zhang YY, Li C, Yao GF, Du LJ, Liu Y, Zheng XJ, et al: Deletion of macrophage mineralocorticoid receptor protects hepatic steatosis and insulin resistance through ERa/HGF/met pathway. Diabetes 2017;66: 1535-1547.

96 Frieler RA, Meng H, Duan SZ, Berger S, Schutz G, He Y, et al: Myeloid-specific deletion of the mineralocorticoid receptor reduces infarct volume and alters inflammation during cerebral ischemia. Stroke 2011; 42:179-185.

97 Rickard AJ, Morgan J, Chrissobolis S, Miller AA, Sobey CG, Young MJ: Endothelial cell mineralocorticoid receptors regulate deoxycorticosterone/salt-mediated cardiac remodeling and vascular reactivity but not blood pressure. Hypertension 2014;63: 1033-1040.

98 Schäfer N, Lohmann C, Winnik S, van Tits LJ, Miranda MX, Vergopoulos A, et al: Endothelial mineralocorticoid receptor activation mediates endothelial dysfunction in diet-induced obesity. Eur Heart J 2013;34:35153524.

99 Jia G, Habibi J, DeMarco VG, Martinez-Lemus LA, Ma L, Whaley-Connell AT, et al: Endothelial mineralocorticoid receptor deletion prevents diet-induced cardiac diastolic dysfunction in females. Hypertension 2015;66:1159-1167.

100 Jia G, Habibi J, Aroor AR, Martinez-Lemus LA, DeMarco VG, Ramirez-Perez FI, et al: Endothelial mineralocorticoid receptor mediates diet-induced aortic stiffness in females. Circ Res 2016;118:935943.

101 McCurley A, Pires PW, Bender SB, Aronovitz M, Zhao MJ, Metzger D, et al: Direct regulation of blood pressure by smooth muscle cell mineralocorticoid receptors. Nat Med 2012;18:1429-1433.

102 Amador CA, Bertocchio JP, Andre-Gregoire G, Placier S, Duong Van Huyen JP, El Moghrabi S, et al: Deletion of mineralocorticoid receptors in smooth muscle cells blunts renal vascular resistance following acute cyclosporine administration. Kidney Int 2016;89:354-362.

103 Galmiche G, Pizard A, Gueret A, El Moghrabi S, Ouvrard-Pascaud A, Berger S, et al: Smooth muscle cell mineralocorticoid receptors are mandatory for aldosterone-salt to induce vascular stiffness. Hypertension 2014;63:520-526.

104 Pruthi D, McCurley A, Aronovitz M, Galayda C, Karumanchi SA, Jaffe IZ: Aldosterone promotes vascular remodeling by direct effects on smooth muscle cell mineralocorticoid receptors. Arterioscler Thromb Vasc Biol 2014;34:355-364. 
105 Rickard AJ, Morgan J, Bienvenu LA, Fletcher EK, Cranston GA, Shen JZ, et al: Cardiomyocyte mineralocorticoid receptors are essential for deoxycorticosterone/salt-mediated inflammation and cardiac fibrosis. Hypertension 2012;60:1443-1450.

106 Fraccarollo D, Berger S, Galuppo P, Kneitz S, Hein L, Schutz G, et al: Deletion of cardiomyocyte mineralocorticoid receptor ameliorates adverse remodeling after myocardial infarction. Circulation 2011;123:400-408.

107 Lother A, Berger S, Gilsbach R, Rösner S, Ecke A, Barreto F, et al: Ablation of mineralocorticoid receptors in myocytes but not in fibroblasts preserves cardiac function. Hypertension 2011;57:746-754

108 Li C, Sun XN, Zeng MR, Zheng XJ, Zhang YY, Wan Q, et al: Mineralocorticoid receptor deficiency in $\mathrm{T}$ cells attenuates pressure overload-induced cardiac hypertrophy and dysfunction through modulating T-cell activation. Hypertension 2017;70:137-147.

109 Pitt B, Reichek N, Willenbrock R, Zannad F, Phillips RA, Roniker B, et al: Effects of eplerenone, enalapril, and eplerenone/enalapril in patients with essential hypertension and left ventricular hypertrophy: the $4 \mathrm{E}-\mathrm{left}$ ventricular hypertrophy study. Circulation 2003; 108:1831-1838
110 Montalescot G, Pitt B, Lopez de Sa E, Hamm $\mathrm{CW}$, Flather M, Verheugt $\mathrm{F}$, et al: Early eplerenone treatment in patients with acute ST-elevation myocardial infarction without heart failure: the Randomized Double-Blind Reminder Study. Eur Heart J 2014;35:22952302.

111 Garg R, Rao AD, Baimas-George M, Hurwitz S, Foster C, Shah RV, et al: Mineralocorticoid receptor blockade improves coronary microvascular function in individuals with type 2 diabetes. Diabetes 2015;64:236242.

112 Epstein M, Williams GH, Weinberger M, Lewin A, Krause S, Mukherjee R, et al: Selective aldosterone blockade with eplerenone reduces albuminuria in patients with type 2 diabetes. Clin J Am Soc Nephrol 2006;1: 940-951.

113 Bianchi S, Bigazzi R, Campese VM: Longterm effects of spironolactone on proteinuria and kidney function in patients with chronic kidney disease. Kidney Int 2006;70: 2116-2123.

114 Furumatsu Y, Nagasawa Y, Tomida K, Mikami S, Kaneko T, Okada N, et al: Effect of renin-angiotensin-aldosterone system triple blockade on non-diabetic renal disease: addition of an aldosterone blocker, spironolac- tone, to combination treatment with an angiotensin-converting enzyme inhibitor and angiotensin II receptor blocker. Hypertens Res 2008;31:59-67.

115 Mehdi UF, Adams-Huet B, Raskin P, Vega GL, Toto RD: Addition of angiotensin receptor blockade or mineralocorticoid antagonism to maximal angiotensin-converting enzyme inhibition in diabetic nephropathy. I Am Soc Nephrol 2009;20:2641-2650.

116 Boesby L, Elung-Jensen T, Klausen TW, Strandgaard S, Kamper AL: Moderate antiproteinuric effect of add-on aldosterone blockade with eplerenone in non-diabetic chronic kidney disease. A Randomized Cross-Over Study. PLoS One 2011;6:e26904.

117 Ando K, Ohtsu H, Uchida S, Kaname S, Arakawa Y, Fujita T, et al: Anti-albuminuric effect of the aldosterone blocker eplerenone in non-diabetic hypertensive patients with albuminuria: a double-blind, randomised, placebo-controlled trial. Lancet Diabetes Endocrinol 2014;2:944-953.

118 Matsumoto Y, Mori Y, Kageyama S, Arihara K, Sugiyama T, Ohmura H, et al: Spironolactone reduces cardiovascular and cerebrovascular morbidity and mortality in hemodialysis patients. J Am Coll Cardiol 2014;63:528536. 